\title{
Variability in protein binding of teicoplanin and achievement of therapeutic drug monitoring targets in critically ill patients: Lessons from the DALI Study
}

\author{
J.A. Roberts ${ }^{\mathrm{a}, \mathrm{b}, *}$, V. Stove $^{\mathrm{c}}$, J.J. De Waele ${ }^{\mathrm{c}}$, B. Sipinkoski ${ }^{\mathrm{d}}$, B. McWhinney ${ }^{\mathrm{d}}$, J.P.J. Ungerer ${ }^{\mathrm{d}}$, \\ M. Akova ${ }^{\mathrm{e}}$, M. Bassetti ${ }^{\mathrm{f}}$, G. Dimopoulos ${ }^{\mathrm{g}}$, K.-M. Kaukonen ${ }^{\mathrm{h}, \mathrm{i}}$, D. Koulenti ${ }^{\mathrm{a}, \mathrm{g}}$, C. Martin $^{\mathrm{j}, \mathrm{k}}$, \\ P. Montravers ${ }^{1}$, J. Rello ${ }^{\mathrm{m}}$, A. Rhodes ${ }^{\mathrm{n}}$, T. Starr ${ }^{\mathrm{b}}$, S.C. Wallis ${ }^{\mathrm{b}}$, J. Lipman ${ }^{\mathrm{a}, \mathrm{b}}$, \\ on behalf of the DALI Study Authors ${ }^{1}$
}

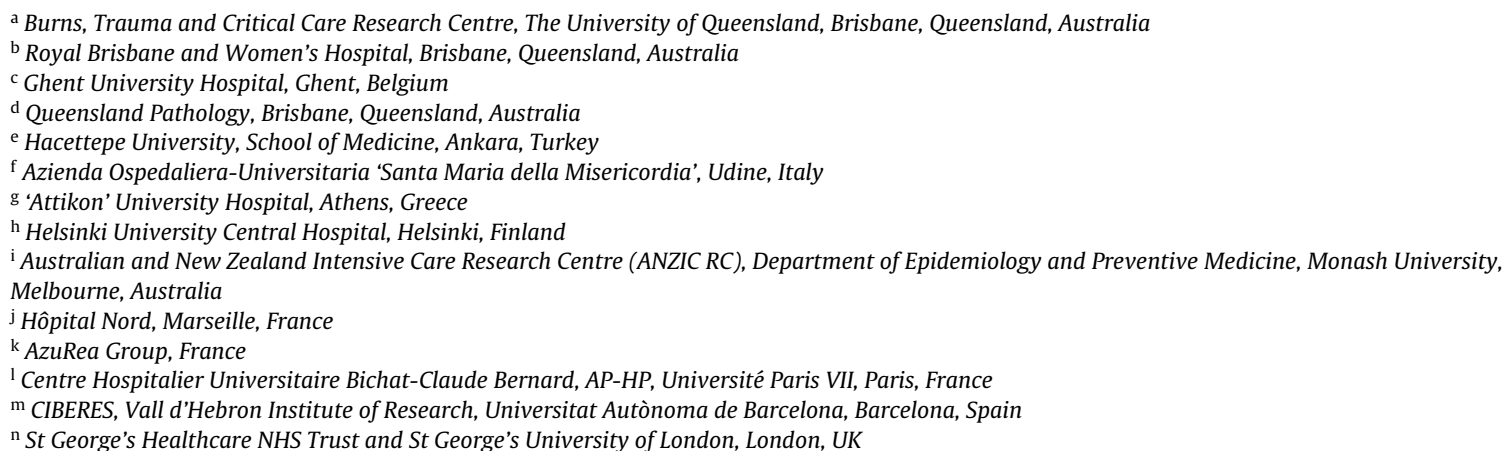

\section{A R T I C L E I N F O}

\section{Article history:}

Received 27 December 2013

Accepted 23 January 2014

\section{Keywords:}

Glycopeptides

Antibiotics

Critically ill patients

Pharmacokinetics

Hypoalbuminaemia

ICU

\begin{abstract}
A B S T R A C T
The aims of this study were to describe the variability in protein binding of teicoplanin in critically ill patients as well as the number of patients achieving therapeutic target concentrations. This report is part of the multinational pharmacokinetic DALI Study. Patients were sampled on a single day, with blood samples taken both at the midpoint and the end of the dosing interval. Total and unbound teicoplanin concentrations were assayed using validated chromatographic methods. The lower therapeutic range of teicoplanin was defined as total trough concentrations from 10 to $20 \mathrm{mg} / \mathrm{L}$ and the higher range as $10-30 \mathrm{mg} / \mathrm{L}$. Thirteen critically ill patients were available for analysis. The following are the median (interquartile range) total and free concentrations $(\mathrm{mg} / \mathrm{L})$ : midpoint, total $13.6(11.2-26.0)$ and free 1.5 $(0.7-2.5)$; trough, total $11.9(10.2-22.7)$ and free $1.8(0.6-2.6)$. The percentage free teicoplanin for the mid-dose and trough time points was $6.9 \%$ (4.5-15.6\%) and 8.2\% (5.5-16.4\%), respectively. The correlation between total and free antibiotic concentrations was moderate for both the midpoint $(\rho=0.79, P=0.0021)$ and trough $(\rho=0.63, P=0.027)$. Only $42 \%$ and $58 \%$ of patients were in the lower and higher therapeutic ranges, respectively. In conclusion, use of standard dosing for teicoplanin leads to inappropriate concentrations in a high proportion of critically ill patients. Variability in teicoplanin protein binding is very high, placing significant doubt on the validity of total concentrations for therapeutic drug monitoring in critically ill patients.
\end{abstract}

(c) 2014 Elsevier B.V. and the International Society of Chemotherapy. All rights reserved.

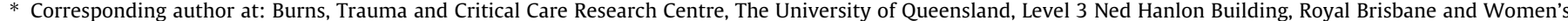
Hospital, Butterfield Street, Brisbane, Queensland 4029, Australia. Tel.: +61 73636 4108; fax: +61 736363542.

E-mail address: j.roberts2@uq.edu.au (J.A. Roberts).

1 DALI Study authors are listed in Appendix.
} 


\section{Introduction}

The incidence of infections due to Gram-positive cocci remains a significant healthcare problem [1]. Coagulase-negative staphylococci (CoNS), Staphylococcus aureus and enterococci are responsible for ca. $40 \%$ of nosocomial infections in the USA and Europe [2]. Moreover, these Gram-positive cocci are becoming more resistant to standard antibiotics. The incidence of meticillin-resistant S. aureus (MRSA) in intensive care units (ICUs) is ca. $50 \%$ in Western and Eastern Europe and up to 65\% in the Americas [2]. CoNS, enterococci and pneumococci are also increasingly resistant both in the USA and Europe. Consequently, use of glycopeptides remains common to treat these pathogens [3]. Although newer antibiotics are currently available as therapy for resistant Gram-positive cocci [4], the two glycopeptide agents vancomycin and teicoplanin remain important treatment options [5]. Teicoplanin is as effective as, considered safer than, but more expensive than, vancomycin [3].

As the bactericidal activity of glycopeptides is largely dependent on the duration of exposure, the ratio of the area under the concentration-time curve to the minimum inhibitory concentration (AUC/MIC) and the time the free drug concentration remains above the MIC $\left(f \mathrm{~T}_{>\mathrm{MIC}}\right)$ are important pharmacodynamic indices for predicting the efficacy of these agents. The targets suggested for vancomycin are $\mathrm{AUC}_{0-24} / \mathrm{MIC} \geq 350$ and $100 \% f \mathrm{~T}_{>4 \times \mathrm{MIC}}[6,7]$. By contrast, for teicoplanin these targets are less clearly defined, particularly in critically ill patients. Moreover, the requirement of multiple plasma concentrations for AUC calculation is not very practical. Therefore, in clinical practice the plasma teicoplanin total trough concentration $\left(C_{\text {trough }}\right)$ is used as a surrogate marker of teicoplanin efficacy. The lower therapeutic range of teicoplanin is commonly defined as total $C_{\text {trough }}$ from $10-20 \mathrm{mg} / \mathrm{L}$ and for severe infections as $20-30 \mathrm{mg} / \mathrm{L}$ [8].

An important characteristic of teicoplanin is its high protein binding (90\%), which can lead to increased pharmacokinetic (PK) variability. Yano et al. demonstrated that plasma albumin concentrations are an important determinant in this variability, with lower albumin concentrations associated with higher unbound fractions of teicoplanin [9]. In critically ill patients, hypoalbuminaemia is a frequent phenomenon [10] and as such teicoplanin PK variability may be significant $[9,11]$. As the unbound or free concentrations are responsible for pharmacological activity, one could theoretically expect higher active concentrations of teicoplanin in these patients. Furthermore, in critically ill patients, renal impairment frequently accompanies hypoalbuminaemia [12]. As clearance of the unbound drug occurs almost exclusively by glomerular filtration, the total body clearance of teicoplanin will decrease with increased renal impairment and will increase with decreases in protein binding $[13,14]$. Augmented renal clearance is also common in critically ill patients, meaning that some patients may develop very low concentrations of renally cleared drugs such as teicoplanin [15-17]. Consequently, free and total plasma concentrations are difficult to predict in critically ill patients.

Recently, a multinational study was conducted that included 68 ICUs and 450 critically ill patients throughout Europe. The Defining Antibiotic Levels in Intensive care unit patients (DALI) Study is a prospective, multicentre PK point-prevalence study describing whether contemporary antibiotic dosing in ICU patients achieves concentrations associated with maximal activity [7,18]. The aims of this report are to describe the variability in protein binding of teicoplanin in critically ill patients as well as the number of patients achieving therapeutic target concentrations.

\section{Materials and methods}

Ethical approval to participate in the DALI Study was obtained at all participating centres, and informed consent was obtained from each patient or their legally authorised representative. The lead site was The University of Queensland (Brisbane, Australia), with ethical approval granted by the Medical Research Ethics Committee (no. 201100283, May 2011). Patients were all identified for participation by ICU clinical staff on the Monday of the nominated sampling week, with blood sampling and data collection occurring throughout that week. For this analysis, patients treated with teicoplanin were studied.

\subsection{Selection of patients}

Inclusion criteria consisted of written informed consent, age $\geq 18$ years, receiving teicoplanin therapy and suitable intravenous/intra-arterial access to facilitate sample collection. Data collection was conducted by trained staff at each participating centre and data were entered onto a case report form (CRF). At the end of the patient's participation, the CRF was sent to the coordinating centre (Burns, Trauma and Critical Care Research Centre, The University of Queensland). Outstanding queries regarding completion of the CRF were undertaken with each participating centre where necessary to ensure accuracy of data.

\subsection{Drug formulation, sampling and assay}

During a single dosing interval of that week, each patient had two blood samples taken for teicoplanin analysis, the first sample at the midpoint of the dosing interval ( $50 \%$ of the dosing interval) and the second sample as a trough concentration immediately before the subsequent dose. Blood was drawn from a catheter different to that in which the antibiotic was infused. After mixing, samples were kept on ice, centrifuged at $3000 \mathrm{rpm}$ for $10 \mathrm{~min}$ within $6 \mathrm{~h}$ of collection and the plasma was transferred to a labelled cryovial for frozen storage (at $-20^{\circ} \mathrm{C}$ or lower for the first 7 days). A commercial courier company specialising in transport of clinical samples on dry ice collected the samples from each site and delivered them to the Burns, Trauma and Critical Care Research Centre at The University of Queensland for bioanalysis. Samples were stored at $-80^{\circ} \mathrm{C}$ until assay.

The concentration of teicoplanin was determined using reversephase high-performance liquid chromatography (HPLC) coupled with ultraviolet (UV) detection. The HPLC system consisted of a Waters 2695 Alliance module and 996 Photodiode array detector (Waters Corp., Milford, MA). Separation of teicoplanin components with a Waters XBridge $C_{18}$ column $(2.5 \mu \mathrm{m}, 4.6 \mathrm{~mm} \times 30 \mathrm{~mm})$ was performed at room temperature. Mobile phase A was comprised of $10 \mathrm{mmol} / \mathrm{L}$ sodium phosphate buffer $(\mathrm{pH} 4.0)$ and mobile phase B was $100 \%$ acetonitrile. A linear gradient increasing from $15 \%$ to $30 \%$ mobile phase B over $15 \mathrm{~min}$ was used. The column was reequilibrated with initial conditions for $2.0 \mathrm{~min}$. UV detection was at $210 \mathrm{~nm}$.

Total teicoplanin sample preparation is a two-step procedure. Plasma $(200 \mu \mathrm{L})$ was mixed with $400 \mu \mathrm{L}$ of acetonitrile in $1.5 \mathrm{~mL}$ Eppendorf tubes and vortexed. After centrifugation ( $5 \mathrm{~min}$, $13,000 \mathrm{rpm}$, room temperature) the supernatant was decanted into $1.5 \mathrm{~mL}$ Eppendorf tubes. Chloroform $(600 \mu \mathrm{L})$ was added, vortexed for $1 \mathrm{~min}$ and centrifuged at $13,000 \mathrm{rpm}$ for $5 \mathrm{~min}$. The aqueous supernatant was then transferred to autosampler vials and $25 \mu \mathrm{L}$ was injected.

Ultrafiltrates of plasma free teicoplanin were prepared by equilibrating $500 \mu \mathrm{L}$ of plasma at $37^{\circ} \mathrm{C}$ for $20 \mathrm{~min}$ in Amicon ${ }^{\circledR}$ Ultra-4 regenerated cellulose 30,000 molecular weight cut-off centrifugal filter devices (Millipore, Billerica, MA) before centrifugation at $3040 \times g$ for $20 \mathrm{~min}$ at $37^{\circ} \mathrm{C}$. The ultrafiltrate was then transferred to autosampler vials and $50 \mu \mathrm{L}$ was injected directly into the HPLC system described above. 
Calibrators of total teicoplanin were prepared in blank plasma spanning a range of $10-50 \mathrm{mg} / \mathrm{L}$. Calibrators of free teicoplanin were prepared in $10 \%$ acetonitrile spanning a range of $0.2-5 \mathrm{mg} / \mathrm{L}$. Low-medium- and high-quality control samples were prepared by spiking teicoplanin into blank plasma and storing the aliquots at $-80^{\circ} \mathrm{C}$.

The assay was linear from $0.2 \mathrm{mg} / \mathrm{L}$ to $5.0 \mathrm{mg} / \mathrm{L}$. Samples containing concentrations $>5.0 \mathrm{mg} / \mathrm{L}$ were diluted in blank plasma and were re-assayed. The intraday and interday coefficients of variation were $<15 \%$.

Serum albumin and creatinine concentrations were measured at the local laboratory connected with the participating ICU.

\subsection{Pharmacokinetic/pharmacodynamic analyses}

Achievement of therapeutic concentrations was assessed according to two therapeutic ranges as previously published for teicoplanin $[13,19]$. The lower therapeutic range included trough concentrations of total teicoplanin from 10 to $20 \mathrm{mg} / \mathrm{L}$, and the higher range, for more severe deep-seated infections, from 20 to $30 \mathrm{mg} / \mathrm{L}$. For this study, the lower therapeutic range of $10-20 \mathrm{mg} / \mathrm{L}$ and a second range of $10-30 \mathrm{mg} / \mathrm{L}$ were used, which encompassed both lower exposures, but also higher exposures up to $30 \mathrm{mg} / \mathrm{L}$ as may be targeted for more severe infections. The $10-30 \mathrm{mg} / \mathrm{L}$ target is included to be a more inclusive grouping.

The area under the curve of teicoplanin plasma concentration versus time from 0 to $24 \mathrm{~h}\left(\mathrm{AUC}_{0-24}\right)$ and other PK parameters were obtained using PharMonitor, a therapeutic drug monitoring (TDM) software based on the Sawchuk-Zaske method and, where necessary, standard non-compartmental equations were used to estimate other PK parameter values [20].

\subsection{Estimation of free teicoplanin concentration}

The calculations were based on the model of Yano et al. [9]:

Free teicoplanin conc. $=\frac{\text { total teicoplanin conc. }}{1+(n \mathrm{Ka} \times \text { serum albumin conc. })}$

where $n \mathrm{Ka}=1.78(\mathrm{~g} / \mathrm{dL})^{-1} ; n$ represents the number of drugbinding sites per albumin molecule with their association constant Ka.

\subsection{Statistical analysis}

Data are reported as median and interquartile range or range. The Pearson $(\rho)$ and Spearman $\left(r_{\mathrm{s}}\right)$ correlation coefficient were used to evaluate the correlation between variables. A $P$-value of $<0.05$ was considered statistically significant. Passing-Bablok regression and statistical analysis were performed using MedCalc (MedCalc Software, Mariakerke, Belgium) and Microsoft Excel (Microsoft Corp., Redmond, WA).

\section{Results}

From the 450 patients who were included in the DALI Study, 13 patients from eight ICUs throughout four countries in Europe were able to be included in this study. Patient characteristics are shown in Table 1. Eight patients were treated with teicoplanin for infections with S. aureus, CoNS or Enterococcus faecalis, whilst in the other patients teicoplanin was given as part of empirical or prophylactic antimicrobial therapy. A range of daily doses $(2.7-20.0 \mathrm{mg} / \mathrm{kg})$ were used at the discretion of the treating clinician. The dosing regimen was documented and differed in terms of dose administered $(400,600$ or $1600 \mathrm{mg}$ ) as well as dosing intervals (every 12,24 or $48 \mathrm{~h}$ ). Six patients were sampled during the first 2
Table 1

Patient characteristics.

\begin{tabular}{|c|c|c|c|c|}
\hline Characteristic & $n$ & Median & IQR & Range \\
\hline No. of patients & 13 & & & \\
\hline No. of male/female & $7 / 6$ & & & \\
\hline Age (years) & & 58 & $41-69$ & $24-75$ \\
\hline Body weight (kg) & & 80 & $72-90$ & $40-115$ \\
\hline \multicolumn{5}{|l|}{ Dose regimen } \\
\hline $1600 \mathrm{mg} \mathrm{q} 24 \mathrm{~h}$ & 1 & & & \\
\hline $600 \mathrm{mg}$ q24h & 1 & & & \\
\hline $400 \mathrm{mg} \mathrm{q} 12 \mathrm{~h}$ & 6 & & & \\
\hline $400 \mathrm{mg} \mathrm{q} 24 \mathrm{~h}$ & 4 & & & \\
\hline $400 \mathrm{mg} \mathrm{q} 48 \mathrm{~h}$ & 1 & & & \\
\hline Dose (mg/kg/day) & & 8.0 & $5.3-8.9$ & $2.7-20.0$ \\
\hline Dose $(\mathrm{mg} / \mathrm{kg})$ & & 5.3 & $4.4-7.7$ & $3.5-17.8$ \\
\hline $\mathrm{SCr}(\mathrm{mg} / \mathrm{dL})^{\mathrm{a}}$ & & 0.98 & $0.67-1.20$ & $0.42-2.14$ \\
\hline Estimated GFR $(\mathrm{mL} / \mathrm{min})^{\mathrm{a}}$ & & 71 & $38-94$ & $25-167$ \\
\hline SAlb $(g / L)^{b}$ & & 28 & $21.5-29.5$ & $17.5-34$ \\
\hline APACHE II score & & 24 & $17-30$ & $3-38$ \\
\hline SOFA score & & 8 & $4-10$ & $2-16$ \\
\hline
\end{tabular}

IQR, interquartile range; q24 h, every 24 h; q12 h, every 12 h; q48 h, every 48 h; SCr, serum creatinine; GFR, glomerular filtration rate; SAlb, serum albumin; APACHE, Acute Physiology and Chronic Health Evaluation; SOFA, Sequential Organ Failure Assessment.

a Excludes three patients receiving continuous renal replacement therapy.

b No data available for two patients.

days of treatment (D1-2), four patients between Days 5 and 11 (D5-11) and three patients during steady state conditions (conservatively defined as $>14$ days after the start of antibiotic treatment).

\subsection{Total teicoplanin target attainment}

The PK parameters are summarised in Table 2. Total $C_{\text {trough }}$ of $10 \mathrm{mg} / \mathrm{L}$ was attained in four of six patients sampled on D1-2, in three of four patients sampled on D5-11 and in two of three patients sampled at steady state. Only $42 \%$ of patients had total trough concentrations of $10-20 \mathrm{mg} / \mathrm{L}$, whilst $58 \%$ had total trough concentrations of $10-30 \mathrm{mg} / \mathrm{L}$ (Fig. 1a). Total teicoplanin concentrations correlated with dosage $\left(R^{2}=0.5996\right.$; Fig. 1b). Based on the data, a dose of $\geq 5 \mathrm{mg} / \mathrm{kg} /$ day was necessary to obtain a total $C_{\text {trough }}$ of $10 \mathrm{mg} / \mathrm{L}$ (data not shown). Selected patient results $(n=10)$ are included in Fig. 1b, showing a positive correlation between teicoplanin concentrations at $12 \mathrm{~h}$ post dosing for a given dose of $400 \mathrm{mg}$ and the dose $/ \mathrm{kg}$. If we presumed that a 12-h dosing interval was used for all patients, three patients would not have attained the target $C_{\text {trough }}$ of $10 \mathrm{mg} / \mathrm{L}$. If we also hypothesised that all patients were given teicoplanin every $24 \mathrm{~h}$, Fig. $1 \mathrm{~b}$ would represent a middose status. In this case, this would result in at least three additional

Table 2

Pharmacokinetic parameters.

\begin{tabular}{|c|c|c|c|}
\hline & Median & IQR & Range \\
\hline \multicolumn{4}{|l|}{ Total teicoplanin } \\
\hline Mid-dose concentration (mg/L) & 13.6 & $11.2-26.0$ & $5.2-49.5$ \\
\hline Trough concentration $(\mathrm{mg} / \mathrm{L})^{\mathrm{a}}$ & 11.9 & $10.2-22.7$ & $4.3-40.5$ \\
\hline $\operatorname{AUC}(\mathrm{mg} \mathrm{h} / \mathrm{L})^{\mathrm{a}}$ & 398 & $318-798$ & $162-6886$ \\
\hline$t_{1 / 2}(\mathrm{~h})^{\mathrm{a}}$ & 31.3 & $19.1-43.5$ & $13.5-88.2$ \\
\hline $\mathrm{CL}(\mathrm{mL} / \mathrm{min} / \mathrm{kg})^{\mathrm{a}}$ & 0.3 & $0.1-0.5$ & $0.02-0.57$ \\
\hline$V_{\mathrm{d}}(\mathrm{L} / \mathrm{kg})^{\mathrm{a}}$ & 0.8 & $0.4-1.1$ & $0.16-1.36$ \\
\hline \multicolumn{4}{|c|}{ Free serum teicoplanin concentration $(\mathrm{mg} / \mathrm{L})$} \\
\hline Mid dose & 1.5 & $0.7-2.5$ & $<0.1-10.0$ \\
\hline Trough $^{\mathrm{a}}$ & 1.8 & $0.6-2.6$ & $0.1-4.5$ \\
\hline \multicolumn{4}{|l|}{ Fraction unbound teicoplanin (\%) } \\
\hline Mid dose & 6.9 & $4.5-15.6$ & $<0.7-28.9$ \\
\hline Trough $^{\mathrm{a}}$ & 8.2 & $5.5-16.4$ & $3.0-28.6$ \\
\hline
\end{tabular}

IQR, interquartile range; AUC, area under the concentration-time curve; $t_{1 / 2}$, halflife; CL, total body clearance; $V_{\mathrm{d}}$, volume of distribution.

a No data for one patient. 
(a)

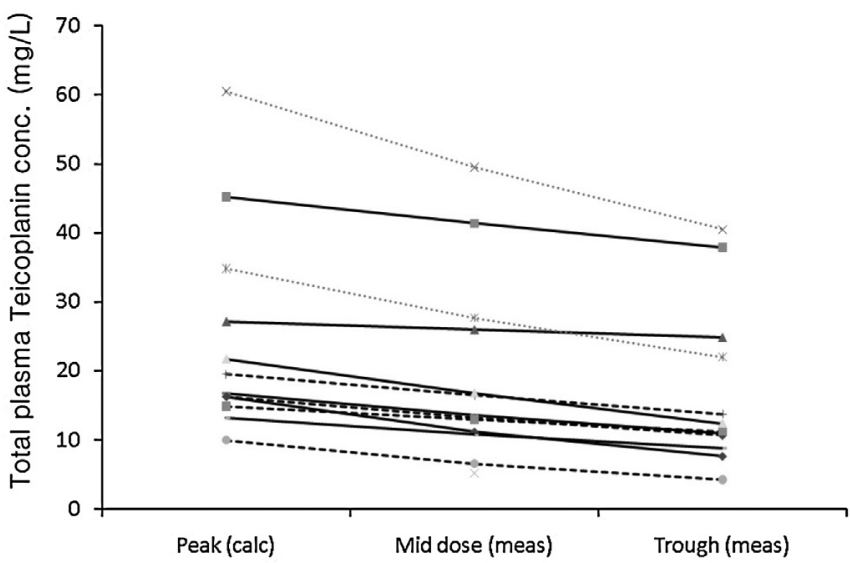

(b)

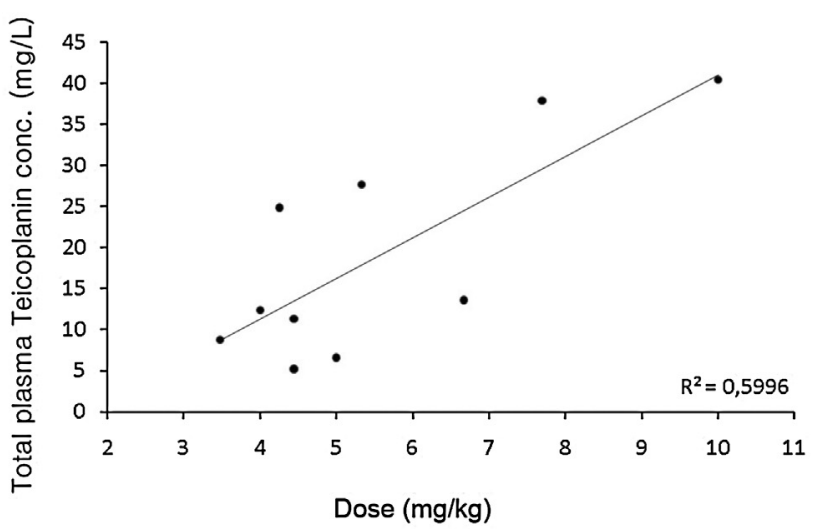

Fig. 1. Total teicoplanin plasma concentration profile. (a) Teicoplanin plasma concentrations for all patients at given time points. Peak (calc.) concentrations are calculated using PharMonitor; mid-dose and trough (measured) concentrations are measured concentrations. Solid line, patients monitored during Days 1-2; dashed line, patients monitored during Days 5-11; grey dotted line, patients monitored during steady state (conservatively defined as $>14$ days after the start of antibiotic treatment). (b) Relationship between dose $/ \mathrm{kg}$ (with a given dose of $400 \mathrm{mg}$ ) and plasma teicoplanin concentration $12 \mathrm{~h}$ post dosing.

patients having a $C_{\text {trough }}$ of $<10 \mathrm{mg} / \mathrm{L}$. In five of the six patients who had concentrations below the target, the dose administered was below the recommended daily $6 \mathrm{mg} / \mathrm{kg}$ dose.

\subsection{Free plasma teicoplanin concentrations}

Free plasma teicoplanin concentrations ranged between $<0.1 \mathrm{mg} / \mathrm{L}$ and $10 \mathrm{mg} / \mathrm{L}$ (mid dose) and $0.1 \mathrm{mg} / \mathrm{L}$ and $4.5 \mathrm{mg} / \mathrm{L}$ (trough). The correlation between total and free antibiotic concentrations for the midpoint and trough concentrations was moderate $[\rho=0.79, P=0.002$ (Fig. 2a) and $\rho=0.63, P=0.027$ (Fig. 2b), respectively]. The impact of plasma albumin concentrations on the fraction of unbound teicoplanin is shown in Fig. 3. High interpatient variation is found in the fraction of free teicoplanin, with higher unbound fractions seen in patients with lower albumin concentrations. Prediction of the free teicoplanin concentrations using the formula of Yano et al. [9] resulted in a highly variable difference between measured and calculated free concentrations (Fig. 4).

\section{Discussion}

In this study, plasma teicoplanin concentrations in critically ill patients were evaluated prospectively. Based on plasma mid-dose and trough concentrations, target attainment during teicoplanin (a)

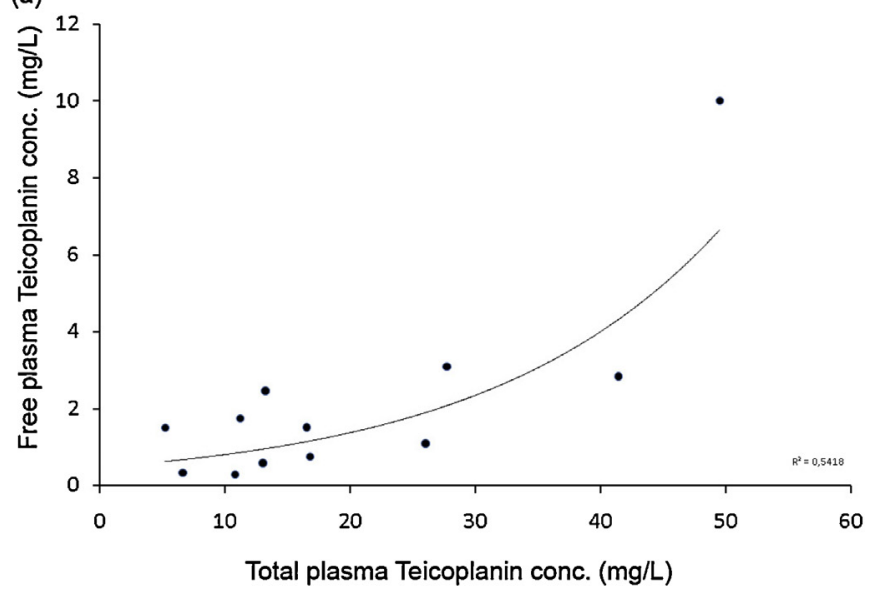

(b)

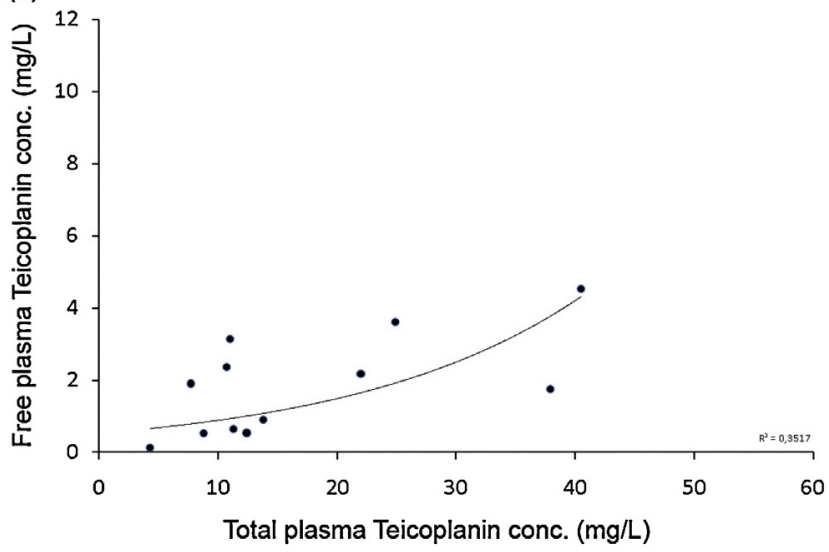

Fig. 2. Relationship between free and total teicoplanin concentration for (a) middose and (b) trough plasma samples. The solid line is least-squares fit to the data. Pearson correlation coefficient of (a) $0.79(P=0.0021)$ and (b) $0.63(P=0.027)$.

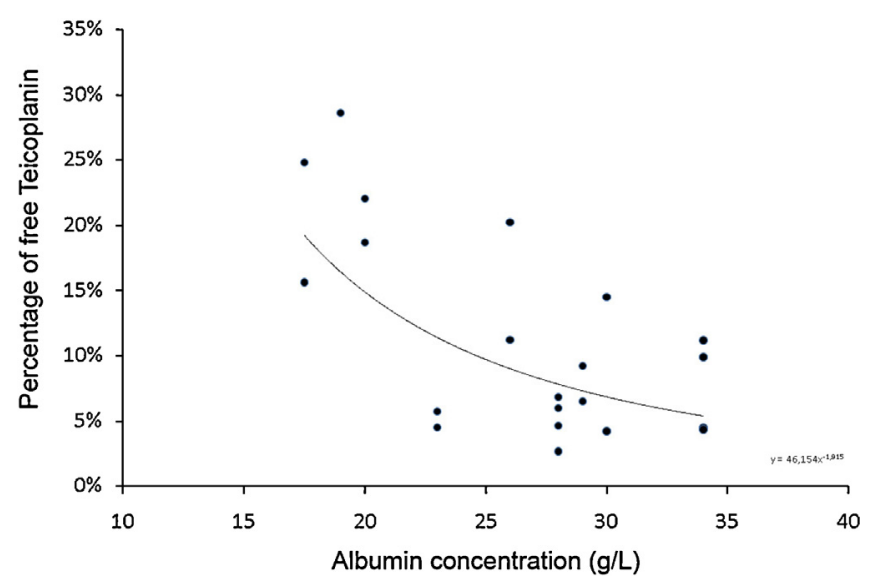

Fig. 3. Impact of plasma albumin concentrations on the percentage of free teicoplanin. Both mid-dose and trough samples are included in the plot. Spearman's coefficient of rank correlation of $-0.56(P=0.0078)$.

treatment was evaluated and inconsistent achievement of target concentrations was observed, whether total or free concentrations are considered. The results suggest that studies evaluating the utility of free concentrations for teicoplanin TDM may help optimise use of this valuable drug.

It is generally accepted that therapeutic teicoplanin concentrations should be $10-20 \mathrm{mg} / \mathrm{L}$ for standard treatment and $20-30 \mathrm{mg} / \mathrm{L}$ for deep-seated infections. Higher concentrations are thought 


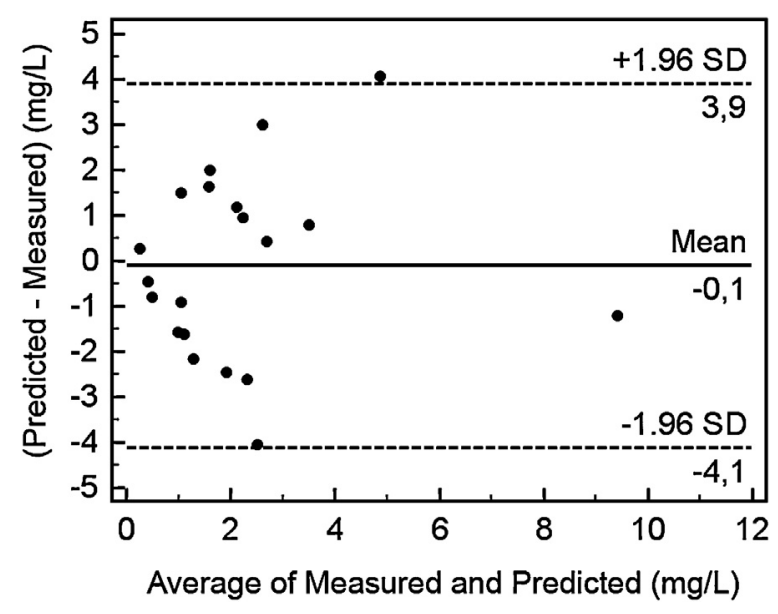

Fig. 4. Absolute difference plot of measured and predicted free plasma teicoplanin concentrations.

to be associated with toxicity, thrombocytopenia when total concentrations exceed $40 \mathrm{mg} / \mathrm{L}$, and nephrotoxicity when above $60 \mathrm{mg} / \mathrm{L}[13,21,22]$. The current results showed high variability in teicoplanin trough concentrations in this critically ill study population, ranging from $4.3 \mathrm{mg} / \mathrm{L}$ to $40.5 \mathrm{mg} / \mathrm{L}$, with $58 \%$ of the population having concentrations between $10 \mathrm{mg} / \mathrm{L}$ and $30 \mathrm{mg} / \mathrm{L}$ (our composite higher target range). To ensure a trough concentration of $\geq 10 \mathrm{mg} / \mathrm{L}$, a minimal daily dose regimen of $6 \mathrm{mg} / \mathrm{kg}$ is required, corresponding with a dose of $400 \mathrm{mg}$ for a person weighing $65 \mathrm{~kg}$. Moreover, a loading dose of 12 -h dosing for the first three doses should be considered [23]. In the current study, a high variability in the dosing regimen was present, and 8 of the 13 patients received a dose $<6 \mathrm{mg} / \mathrm{kg}$, mainly because doses were not adjusted to the weight of these patients, all weighing $\geq 75 \mathrm{~kg}$.

Teicoplanin differs from vancomycin principally by virtue of its high protein binding. This high protein binding results in a long elimination half-life. Consequently, it can take days to reach steady-state conditions. However, subtherapeutic concentrations during the first few days of treatment may contribute to treatment failure and hence should be avoided. Hypoalbuminaemia is a commonly encountered condition in critically ill patients, leading to altered unbound antibiotic fractions and hence a decrease in correlation between free and total antibiotic concentrations [24]. In the patient population studied here, all documented albumin concentrations were below the normal reference range and 4 of 11 patients had hypoalbuminaemia according to the definition from the SAFE Study (albumin $<25 \mathrm{~g} / \mathrm{L}$ ) [10]. A high variability in teicoplanin protein binding was found, ranging from $71 \%$ to $97 \%$, with higher free fractions observed in patients with lower albumin concentrations. The correlation between teicoplanin free fraction and albumin concentration has also been addressed by Yano et al. who included 198 serum samples in their analysis [9]. The equation for calculating free teicoplanin concentrations from total concentrations and serum albumin concentrations from Yano et al. is a valuable addition; however, in our hands, this estimation was not found to be sufficiently accurate.

A major concern in the interpretation of unbound concentrations is that no validated targets for unbound TDM are available. Given teicoplanin has $90 \%$ protein binding in patients without hypoalbuminaemia, we would hypothesise that the lower therapeutic range of free plasma teicoplanin trough concentration should be 1-2 mg/L. In this patient population, achievement of free $C_{\text {trough }}$ targets was not able to be predicted from total $C_{\text {trough }}$ values in $33 \%$ of patients.

This study has some limitations that should be addressed. Most importantly, this study only included a small number of patients and these were sampled on different days of therapy in this pointprevalence study. Second, no clinical outcome data correlations were possible. Third, dosing was not standardised in these patients, but this reflects current clinical practice and provides more generalisability of the results. Finally, it is possible that some variability may exist in the different analytical methods and instruments used to measure albumin concentrations, although these methods are each independently validated.

We can conclude that the variability in teicoplanin protein binding is very high in critically ill patients, placing significant doubt on the validity of total concentrations for TDM. Consequently, monitoring of free teicoplanin concentrations appears to be an appropriate step forward in the treatment of critically ill patients and should be tested in a prospective study.

\section{Authors' contribution}

J. Roberts, J. De Waele, M. Akova, K.-M. Kaukonen, D. Koulenti, C. Martin, P. Montravers, J. Rello, A. Rhodes, T. Starr, S. Wallis, J. Lipman carried out conception and designing of the study. Acquisition of data: laboratory or clinical and analysis of data were done by J. Roberts, V. Stove, J. De Waele, B. Sipinkoski, B. McWhinney, J Ungerer, M. Akova, M Bassetti, G. Dimopoulos, K.-M. Kaukonen, D. Koulenti, C. Martin, P. Montravers, J. Rello, A. Rhodes, T. Starr, S. Wallis and J. Lipman. Drafting of article and/or critical revision were done by all authors. All authors are approved the final manuscript.

Funding: This study was partly funded by the European Society of Intensive Care Medicine and the Royal Brisbane and Women's Hospital Foundation, Australia. Neither of these grants are considered a conflict of interest by the authors. JAR is supported in part by a Career Development Fellowship from the Australian National Health and Medical Research Council [NHMRC APP1048652].

Competing interests: None declared.

Ethical approval: The lead site was The University of Queensland (Brisbane, Australia) with ethical approval granted by the Medical Research Ethics Committee [no. 201100283, May 2011].

\section{Appendix. DALI Study Group}

\begin{tabular}{ll}
\hline Author name & Affiliation \\
\hline Jason A. Roberts & Burns, Trauma and Critical Care Research \\
& Centre, The University of Queensland, \\
& Brisbane, Australia; Royal Brisbane and \\
& Women's Hospital, Brisbane, Australia \\
& Burns, Trauma and Critical Care Research \\
Jeffrey Lipman & Centre, The University of Queensland, \\
& Brisbane, Australia; Royal Brisbane and \\
& Women's Hospital, Brisbane, Australia \\
Therese Starr & Royal Brisbane and Women's Hospital, \\
& Brisbane, Australia \\
Steven C. Wallis & Burns, Trauma and Critical Care Research \\
& Centre, The University of Queensland, \\
Sanjoy Paul & Brisbane, Australia \\
& Queensland Clinical Trials \& Biostatistics \\
Antonio Margarit Ribas & Centre, School of Population Health, The \\
Jan J. De Waele & Hospital Nostra Senyora de Meritxell, \\
Luc De Crop & Escaldes-Engordany, Andorra \\
Herbert Spapen & Ghent University Hospital, Ghent, Belgium \\
Joost Wauters & Ghent University Hospital, Ghent, Belgium \\
& Universitair Ziekenhuis Brussels, Brussels, \\
Ilse Dapper & Belgium \\
& Universitair Ziekenhuis Gasthuisberg, Leuven, \\
& Belgium \\
& Clinique Saint-Pierre, Ottignies, Belgium \\
& Universitair Ziekenhuis Antwerpen, Edegem, \\
& Belgium \\
& Algemeen Ziekenhuis Monica, Deurne, Belgium
\end{tabular}




\section{Appendix (Continued)}

\begin{tabular}{|c|c|}
\hline Author name & Affiliation \\
\hline Daniel De Backer & Erasme University Hospital, Brussels, Belgium \\
\hline Fabio S. Taccone & Erasme University Hospital, Brussels, Belgium \\
\hline Jordi Rello & $\begin{array}{l}\text { Vall d'Hebron Institute of Research, Universitat } \\
\text { Autònoma de Barcelona, Spain; Centro de } \\
\text { Investigación Biomedica en } \\
\text { Red-Enfermedades Respiratorias (CIBERES) }\end{array}$ \\
\hline Laura Ruano & $\begin{array}{l}\text { Vall d'Hebron Institute of Research, Universitat } \\
\text { Autònoma de Barcelona, Spain; Centro de } \\
\text { Investigación Biomedica en } \\
\text { Red-Enfermedades Respiratorias (CIBERES) }\end{array}$ \\
\hline Elsa Afonso & $\begin{array}{l}\text { Hospital Universitari Vall d'Hebron, Vall } \\
\text { d'Hebron Institute of Research, Universitat } \\
\text { Autònoma de Barcelona, Spain; Centro de } \\
\text { Investigación Biomedica en } \\
\text { Red-Enfermedades Respiratorias (CIBERES) }\end{array}$ \\
\hline $\begin{array}{l}\text { Francisco } \\
\text { Alvarez-Lerma }\end{array}$ & $\begin{array}{l}\text { Hospital del Mar, Parc de Salut Mar, Barcelona, } \\
\text { Spain }\end{array}$ \\
\hline $\begin{array}{l}\text { Maria Pilar } \\
\text { Gracia-Arnillas }\end{array}$ & $\begin{array}{l}\text { Hospital del Mar, Parc de Salut Mar, Barcelona, } \\
\text { Spain }\end{array}$ \\
\hline Francisco Fernández & Centro Médico Delfos, Barcelona, Spain \\
\hline Neus Feijoo & $\begin{array}{l}\text { Hospital General de L'hospitalet, Barcelona, } \\
\text { Spain }\end{array}$ \\
\hline Neus Bardolet & $\begin{array}{l}\text { Hospital General de L'hospitalet, Barcelona, } \\
\text { Spain }\end{array}$ \\
\hline Assumpta Rovira & $\begin{array}{l}\text { Hospital General de L'hospitalet, Barcelona, } \\
\text { Spain }\end{array}$ \\
\hline Pau Garro & $\begin{array}{l}\text { Hospital General de Granollers, Barcelona, } \\
\text { Spain }\end{array}$ \\
\hline Diana Colon & $\begin{array}{l}\text { Hospital General de Granollers, Barcelona, } \\
\text { Spain }\end{array}$ \\
\hline Carlos Castillo & Hospital Txagorritxu, Vitoria, Spain \\
\hline Juan Fernado & Hospital Txagorritxu, Vitoria, Spain \\
\hline Maria Jesus Lopez & Hospital Universitario de Burgos, Burgos, Spain \\
\hline Jose Luis Fernandez & Hospital Universitario de Burgos, Burgos, Spain \\
\hline Ana Maria Arribas & Hospital Universitario de Burgos, Burgos, Spain \\
\hline Jose Luis Teja & $\begin{array}{l}\text { Hospital Universitario Marqués de Valdecilla, } \\
\text { Santander, Spain }\end{array}$ \\
\hline Elsa Ots & $\begin{array}{l}\text { Hospital Universitario Marqués de Valdecilla, } \\
\text { Santander, Spain }\end{array}$ \\
\hline Juan Carlos Montejo & $\begin{array}{l}\text { Hospital Universitario } 12 \text { de Octubre, Madrid, } \\
\text { Spain }\end{array}$ \\
\hline Mercedes Catalan & $\begin{array}{l}\text { Hospital Universitario } 12 \text { de Octubre, Madrid, } \\
\text { Spain }\end{array}$ \\
\hline Isidro Prieto & Hospital Ramon y Cajal, Madrid, Spain \\
\hline Gloria Gonzalo & Hospital Ramon y Cajal, Madrid, Spain \\
\hline Beatriz Galvan & Hospital Universitario La Paz, Madrid, Spain \\
\hline Miguel Angel Blasco & $\begin{array}{l}\text { Hospital Universitario Severo Ochoa, Madrid, } \\
\text { Spain }\end{array}$ \\
\hline Estibaliz Meyer & $\begin{array}{l}\text { Hospital Universitario Severo Ochoa, Madrid, } \\
\text { Spain }\end{array}$ \\
\hline Frutos Del Nogal & $\begin{array}{l}\text { Hospital Universitario Severo Ochoa, Madrid, } \\
\text { Spain }\end{array}$ \\
\hline Loreto Vidaur & $\begin{array}{l}\text { Hospital Universitario de Donostia, Donostia, } \\
\text { Spain }\end{array}$ \\
\hline Rosa Sebastian & $\begin{array}{l}\text { Hospital Universitario de Donostia, Donostia, } \\
\text { Spain }\end{array}$ \\
\hline Pila Marco Garde & $\begin{array}{l}\text { Hospital Universitario de Donostia, Donostia, } \\
\text { Spain }\end{array}$ \\
\hline Maria del Mar Martin & Hospital Universitario Nuestra Señora de \\
\hline Velasco & Candelaria, Santa Cruz de Tenerife, Spain \\
\hline Rafael Zaragoza Crespo & Hospital Universitario Dr Peset, València, Spain \\
\hline Mariano Esperatti & $\begin{array}{l}\text { Institut Clínic del Tòrax, Hospital Clinic, } \\
\text { IDIBAPS, Barcelona, Spain; Centro de } \\
\text { Investigación Biomedica en } \\
\text { Red-Enfermedades Respiratorias (CIBERES) }\end{array}$ \\
\hline Antoni Torres & $\begin{array}{l}\text { Institut Clínic del Tòrax, Hospital Clinic, } \\
\text { IDIBAPS, Barcelona, Spain; Centro de } \\
\text { Investigación Biomedica en } \\
\text { Red-Enfermedades Respiratorias (CIBERES) }\end{array}$ \\
\hline Philippe Montravers & $\begin{array}{l}\text { Centre Hospitalier Universitaire Bichat-Claude } \\
\text { Bernard, AP-HP, Université Paris VII, Paris, } \\
\text { France }\end{array}$ \\
\hline Olivier Baldesi & $\begin{array}{l}\text { Centre Hospitalier Pays D Aix, } \\
\text { Aix-en-Provence, France; AzuRea Group, } \\
\text { France }\end{array}$ \\
\hline Herve Dupont & $\begin{array}{l}\text { Centre Hospitalier Universitaire d'Amiens, } \\
\text { Amiens, France }\end{array}$ \\
\hline
\end{tabular}

Appendix (Continued)

\begin{tabular}{|c|c|}
\hline Author name & Affiliation \\
\hline Yazine Mahjoub & $\begin{array}{l}\text { Centre Hospitalier-Universitaire d'Amiens, } \\
\text { Amiens, France; AzuRea Group, France }\end{array}$ \\
\hline Sigismond Lasocki & $\begin{array}{l}\text { Centre Hospitalier-Universitaire d'Angers, } \\
\text { Angers, France }\end{array}$ \\
\hline Jean Michel Constantin & $\begin{array}{l}\text { Centre Hospitalier Universitaire de } \\
\text { Clermont-Ferrand, Clermont-Ferrand, France; } \\
\text { AzuRea Group, France }\end{array}$ \\
\hline Jean François Payen & $\begin{array}{l}\text { Centre Hospitalier-Universitaire Grenoble, } \\
\text { Grenoble, France; AzuRea Group, France }\end{array}$ \\
\hline Claude Martin & $\begin{array}{l}\text { Hôpital Nord, Marseille, France; AzuRea Group, } \\
\text { France }\end{array}$ \\
\hline Jacques Albanese & $\begin{array}{l}\text { Hôpital Nord, Marseille, France; AzuRea Group, } \\
\text { France }\end{array}$ \\
\hline Yannick Malledant & Hôpital Pontchaillou, Rennes, France \\
\hline Julien Pottecher & $\begin{array}{l}\text { University Hospital, Strasbourg, France; } \\
\text { AzuRea Group, France }\end{array}$ \\
\hline Jean-Yves Lefrant & $\begin{array}{l}\text { Centre Hospitalier-Universitaire Nimes, Nimes, } \\
\text { France; AzuRea Group, France }\end{array}$ \\
\hline Samir Jaber & $\begin{array}{l}\text { Hospitalier-Universitaire Montpellier, } \\
\text { Montpellier, France; AzuRea Group, France }\end{array}$ \\
\hline Olivier Joannes-Boyau & $\begin{array}{l}\text { Centre Hospitalier-Universitaire Bordeaux, } \\
\text { Bordeaux, France; AzuRea Group, France }\end{array}$ \\
\hline Christophe Orban & $\begin{array}{l}\text { Centre Hospitalier-Universitaire Nice, Nice, } \\
\text { France; AzuRea Group, France }\end{array}$ \\
\hline Marlies Ostermann & St Thomas' Hospital, London, UK \\
\hline Catherine McKenzie & St Thomas' Hospital, London, UK \\
\hline Willaim Berry & St Thomas' Hospital, London, UK \\
\hline John Smith & St Thomas' Hospital, London, UK \\
\hline Katie Lei & St Thomas' Hospital, London, UK \\
\hline Francesca Rubulotta & $\begin{array}{l}\text { Charing Cross Hospital, Imperial Healthcare } \\
\text { NHS Trust, London, UK }\end{array}$ \\
\hline Anthony Gordon & $\begin{array}{l}\text { Charing Cross Hospital, Imperial Healthcare } \\
\text { NHS Trust, London, UK }\end{array}$ \\
\hline Stephen Brett & $\begin{array}{l}\text { Hammersmith Hospital, Imperial Healthcare } \\
\text { NHS Trust, London, UK }\end{array}$ \\
\hline Martin Stotz & $\begin{array}{l}\text { St Mary's Hospital, Imperial Healthcare NHS } \\
\text { Trust, London, UK }\end{array}$ \\
\hline Maie Templeton & $\begin{array}{l}\text { St Mary's Hospital, Imperial Healthcare NHS } \\
\text { Trust, London, UK }\end{array}$ \\
\hline Andrew Rhodes & $\begin{array}{l}\text { St George's Hospital, St George's Healthcare } \\
\text { NHS Trust, London, UK }\end{array}$ \\
\hline Claudia Ebm & $\begin{array}{l}\text { St George's Hospital, St George's Healthcare } \\
\text { NHS Trust, London, UK }\end{array}$ \\
\hline Carl Moran & $\begin{array}{l}\text { St George's Hospital, St George's Healthcare } \\
\text { NHS Trust, London, UK }\end{array}$ \\
\hline Kirsi-Maija Kaukonen & $\begin{array}{l}\text { Helsinki University Central Hospital, Helsinki, } \\
\text { Finland }\end{array}$ \\
\hline Ville Pettilä & $\begin{array}{l}\text { Helsinki University Central Hospital, Helsinki, } \\
\text { Finland }\end{array}$ \\
\hline George Dimopoulos & ‘Attikon’ University Hospital, Athens, Greece \\
\hline Despoina Koulenti & 'Attikon' University Hospital, Athens, Greece \\
\hline Aglaia Xristodoulou & ‘Attikon' University Hospital, Athens, Greece \\
\hline Vassiliki Theodorou & $\begin{array}{l}\text { University Hospital of Alexandroupolis, } \\
\text { Alexandroupolis, Greece }\end{array}$ \\
\hline Georgios Kouliatsis & $\begin{array}{l}\text { University Hospital of Alexandroupolis, } \\
\text { Alexandroupolis, Greece }\end{array}$ \\
\hline Eleni Sertaridou & $\begin{array}{l}\text { University Hospital of Alexandroupolis, } \\
\text { Alexandroupolis, Greece }\end{array}$ \\
\hline Georgios Anthopoulos & $\begin{array}{l}251 \text { Air Force General Hospital of Athens, } \\
\text { Athens, Greece }\end{array}$ \\
\hline George Choutas & $\begin{array}{l}251 \text { Air Force General Hospital of Athens, } \\
\text { Athens, Greece }\end{array}$ \\
\hline Thanos Rantis & $\begin{array}{l}251 \text { Air Force General Hospital of Athens, } \\
\text { Athens, Greece }\end{array}$ \\
\hline Stylianos Karatzas & $\begin{array}{l}\text { General Hospital of Athens 'Hippokrateion', } \\
\text { Athens, Greece }\end{array}$ \\
\hline Margarita Balla & $\begin{array}{l}\text { General Hospital of Athens 'Hippokrateion', } \\
\text { Athens, Greece }\end{array}$ \\
\hline Metaxia Papanikolaou & $\begin{array}{l}\text { General Hospital of Athens 'Hippokrateion', } \\
\text { Athens, Greece }\end{array}$ \\
\hline Pavlos Myrianthefs & ‘Aghioi Anargyroi’ Hospital, Athens, Greece \\
\hline Alexandra Gavala & 'Aghioi Anargyroi' Hospital, Athens, Greece \\
\hline Georgios Fildisis & ‘Aghioi Anargyroi’ Hospital, Athens, Greece \\
\hline Antonia Koutsoukou & Sotiria General Hospital, Athens, Greece \\
\hline $\begin{array}{l}\text { Magdalini } \\
\text { Kyriakopoulou }\end{array}$ & Sotiria General Hospital, Athens, Greece \\
\hline Kalomoira Petrocl & tiria General Hospital, Athens, Greece \\
\hline
\end{tabular}


Appendix (Continued)

\begin{tabular}{|c|c|}
\hline Author name & Affiliation \\
\hline Maria Kompoti & $\begin{array}{l}\text { 'Thriassio' General Hospital of Eleusis, Athens, } \\
\text { Greece }\end{array}$ \\
\hline Martha Michalia & $\begin{array}{l}\text { 'Thriassio' General Hospital of Eleusis, Athens, } \\
\text { Greece }\end{array}$ \\
\hline $\begin{array}{l}\text { Fillis-Maria } \\
\text { Clouva-Molyvdas }\end{array}$ & $\begin{array}{l}\text { 'Thriassio' General Hospital of Eleusis, Athens, } \\
\text { Greece }\end{array}$ \\
\hline Georgios Gkiokas & Aretaieion University Hospital, Athens, Greece \\
\hline Fotios Nikolakopoulos & Aretaieion University Hospital, Athens, Greece \\
\hline Vasiliki Psychogiou & Aretaieion University Hospital, Athens, Greece \\
\hline Polychronis Malliotakis & University Hospital Herakleion, Crete, Greece \\
\hline Evangelia Akoumianaki & University Hospital Herakleion, Crete, Greece \\
\hline Emmanouil Lilitsis & University Hospital Herakleion, Crete, Greece \\
\hline Vassilios Koulouras & $\begin{array}{l}\text { University Hospital of Ioannina, Ioannina, } \\
\text { Greece }\end{array}$ \\
\hline George Nakos & $\begin{array}{l}\text { University Hospital of Ioannina, Ioannina, } \\
\text { Greece }\end{array}$ \\
\hline Mihalis Kalogirou & $\begin{array}{l}\text { University Hospital of Ioannina, Ioannina, } \\
\text { Greece }\end{array}$ \\
\hline Apostolos Komnos & General Hospital of Larisa, Larisa, Greece \\
\hline Tilemachos Zafeiridis & General Hospital of Larisa, Larisa, Greece \\
\hline Christos Chaintoutis & General Hospital of Larisa, Larisa, Greece \\
\hline Kostoula Arvaniti & $\begin{array}{l}\text { General Hospital of Thessaloniki ‘G. } \\
\text { Papageorgiou', Thessaloniki, Greece }\end{array}$ \\
\hline Dimitrios Matamis & $\begin{array}{l}\text { General Hospital of Thessaloniki ‘G. } \\
\text { Papageorgiou’, Thessaloniki, Greece }\end{array}$ \\
\hline Christos Chaintoutis & $\begin{array}{l}\text { General Hospital of Thessaloniki ‘G. } \\
\text { Papageorgiou', Thessaloniki, Greece }\end{array}$ \\
\hline Christina Kydona & $\begin{array}{l}\text { General Hospital of Thessaloniki } \\
\text { 'Hippokrateion', Thessaloniki, Greece }\end{array}$ \\
\hline Nikoleta & General Hospital of Thessaloniki \\
\hline Gritsi-Gerogianni & 'Hippokrateion', Thessaloniki, Greece \\
\hline Tatiana Giasnetsova & $\begin{array}{l}\text { General Hospital of Thessaloniki } \\
\text { 'Hippokrateion', Thessaloniki, Greece }\end{array}$ \\
\hline Maria Giannakou & $\begin{array}{l}\text { AHEPA University Hospital, Thessaloniki, } \\
\text { Greece }\end{array}$ \\
\hline Ioanna Soultati & $\begin{array}{l}\text { AHEPA University Hospital, Thessaloniki, } \\
\text { Greece }\end{array}$ \\
\hline Ilias Chytas & $\begin{array}{l}\text { AHEPA University Hospital, Thessaloniki, } \\
\text { Greece }\end{array}$ \\
\hline Eleni Antoniadou & $\begin{array}{l}\text { General Hospital 'G. Gennimatas', Thessaloniki, } \\
\text { Greece }\end{array}$ \\
\hline Elli Antipa & $\begin{array}{l}\text { General Hospital 'G. Gennimatas', Thessaloniki, } \\
\text { Greece }\end{array}$ \\
\hline Dimitrios Lathyris & $\begin{array}{l}\text { General Hospital 'G. Gennimatas', Thessaloniki, } \\
\text { Greece }\end{array}$ \\
\hline $\begin{array}{l}\text { Triantafyllia } \\
\text { Koukoubani }\end{array}$ & General Hospital of Trikala, Trikala, Greece \\
\hline Theoniki Paraforou & General Hospital of Trikala, Trikala, Greece \\
\hline Kyriaki Spiropoulou & General Hospital of Trikala, Trikala, Greece \\
\hline Vasileios Bekos & Naval Hospital of Athens, Athens, Greece \\
\hline Anna Spring & Naval Hospital of Athens, Athens, Greece \\
\hline Theodora Kalatzi & Naval Hospital of Athens, Athens, Greece \\
\hline Hara Nikolaou & $\begin{array}{l}\text { ‘Aghia Olga-Konstantopouleion’ General } \\
\text { Hospital, Athens, Greece }\end{array}$ \\
\hline Maria Laskou & $\begin{array}{l}\text { 'Aghia Olga-Konstantopouleion' General } \\
\text { Hospital, Athens, Greece }\end{array}$ \\
\hline Ioannis Strouvalis & $\begin{array}{l}\text { 'Aghia Olga-Konstantopouleion' General } \\
\text { Hospital, Athens, Greece }\end{array}$ \\
\hline Stavros Aloizos & $\begin{array}{l}\text { General Hospital of Athens 'NIMITS', Athens, } \\
\text { Greece }\end{array}$ \\
\hline Spyridon Kapogiannis & $\begin{array}{l}\text { General Hospital of Athens 'NIMITS', Athens, } \\
\text { Greece }\end{array}$ \\
\hline Ourania Soldatou & $\begin{array}{l}\text { General Hospital of Athens 'NIMITS', Athens, } \\
\text { Greece }\end{array}$ \\
\hline Matteo Bassetti & $\begin{array}{l}\text { Azienda Ospedaliera-Universitaria ‘Santa } \\
\text { Maria della Misericordia', Udine, Italy }\end{array}$ \\
\hline Chiara Adembri & $\begin{array}{l}\text { Azienda Ospedaliero-Universitaria Careggi, } \\
\text { Florence, Italy }\end{array}$ \\
\hline Gianluca Villa & $\begin{array}{l}\text { Azienda Ospedaliero-Universitaria Careggi, } \\
\text { Florence, Italy }\end{array}$ \\
\hline Antonio Giarratano & $\begin{array}{l}\text { Università degli Studi di Palermo, Palermo, } \\
\text { Italy }\end{array}$ \\
\hline Santi Maurizio Raineri & $\begin{array}{l}\text { Università degli Studi di Palermo, Palermo, } \\
\text { Italy }\end{array}$ \\
\hline
\end{tabular}

Appendix (Continued)

\begin{tabular}{|c|c|}
\hline Author name & Affiliation \\
\hline Andrea Cortegiani & $\begin{array}{l}\text { Università degli Studi di Palermo, Palermo, } \\
\text { Italy }\end{array}$ \\
\hline Francesca Montalto & $\begin{array}{l}\text { Università degli Studi di Palermo, Palermo, } \\
\text { Italy }\end{array}$ \\
\hline Maria Teresa Strano & $\begin{array}{l}\text { Università degli Studi di Palermo, Palermo, } \\
\text { Italy }\end{array}$ \\
\hline V. Marco Ranieri & San Giovanni-Battista Molinette, Turin, Italy \\
\hline Claudio Sandroni & $\begin{array}{l}\text { Catholic University School of Medicine, Rome, } \\
\text { Italy }\end{array}$ \\
\hline Gennaro De Pascale & $\begin{array}{l}\text { Catholic University School of Medicine, Rome, } \\
\text { Italy }\end{array}$ \\
\hline Alexandre Molin & University of Genoa, Genoa, Italy \\
\hline Paolo Pelosi & University of Genoa, Genoa, Italy \\
\hline Luca Montagnani & Universitaria San Martino, Genova, Italy \\
\hline Rosario Urbino & $\begin{array}{l}\text { Universitaria S. Giovanni Battista della Città di } \\
\text { Torino, Torino, Italy }\end{array}$ \\
\hline Ilaria Mastromauro & $\begin{array}{l}\text { Universitaria S. Giovanni Battista della Città di } \\
\text { Torino, Torino, Italy }\end{array}$ \\
\hline Francesco G. De Rosa & $\begin{array}{l}\text { Universitaria S. Giovanni Battista della Città di } \\
\text { Torino, Torino, Italy }\end{array}$ \\
\hline V. Marco Ranieri & $\begin{array}{l}\text { Universitaria S. Giovanni Battista della Città di } \\
\text { Torino, Torino, Italy }\end{array}$ \\
\hline Teresa Cardoso & Hospital de Santo António, Porto, Portugal \\
\hline Susana Afonso & $\begin{array}{l}\text { Hospital de St António dos Capuchos, Lisbon, } \\
\text { Portugal }\end{array}$ \\
\hline João Gonçalves-Pereira & $\begin{array}{l}\text { Hospital de São Francisco Xavier, Lisbon, } \\
\text { Portugal }\end{array}$ \\
\hline João Pedro Baptista & $\begin{array}{l}\text { Hospitais de Universidade de Coimbra, } \\
\text { Coimbra, Portugal }\end{array}$ \\
\hline Murat Akova & $\begin{array}{l}\text { Hacettepe University School of Medicine, } \\
\text { Ankara, Turkey }\end{array}$ \\
\hline Arife Özveren & $\begin{array}{l}\text { Hacettepe University School of Medicine, } \\
\text { Ankara, Turkey }\end{array}$ \\
\hline
\end{tabular}

\section{References}

[1] Stryjewski ME, Corey GR. Methicillin-resistant Staphylococcus aureus: an evolving pathogen. Clin Infect Dis 2014;58(Suppl. 1):S10-19.

[2] Vincent JL, Rello J, Marshall J, Silva E, Anzueto A, Martin CD, et al. International study of the prevalence and outcomes of infection in intensive care units. J Am Med Assoc 2009;302:2323-9.

[3] Ziglam HM, Finch RG. Limitations of presently available glycopeptides in the treatment of Gram-positive infection. Clin Microbiol Infect 2001;7(Suppl 4):53-65.

[4] Lentino JR, Narita M, Yu VL. New antimicrobial agents as therapy for resistant Gram-positive cocci. Eur J Clin Microbiol Infect Dis 2008;27:3-15.

[5] Alvarez-Lerma F, Grau S. Management of antimicrobial use in the intensive care unit. Drugs 2012;72:447-70.

[6] Rybak MJ, Lomaestro BM, Rotschafer JC, Moellering RC, Craig WA, Billeter M, et al. Vancomycin therapeutic guidelines: a summary of consensus recommendations from the Infectious Diseases Society of America, the American Society of Health-System Pharmacists, and the Society of Infectious Diseases Pharmacists. Clin Infect Dis 2009;49:325-7.

[7] Roberts JA, De Waele JJ, Dimopoulos G, Koulenti D, Martin C, Montravers P, et al DALI: Defining Antibiotic Levels in Intensive care unit patients: a multi-centre point of prevalence study to determine whether contemporary antibiotic dosing for critically ill patients is therapeutic. BMC Infect Dis 2012;12:152.

[8] Roberts JA, Norris R, Paterson DL, Martin JH. Therapeutic drug monitoring of antimicrobials. Br J Clin Pharmacol 2012;73:27-36.

[9] Yano R, Nakamura T, Tsukamoto H, Igarashi T, Goto N, Wakiya Y, et al. Variability in teicoplanin protein binding and its prediction using serum albumin concentrations. Ther Drug Monit 2007;29:399-403.

[10] Finfer S, McEvoy S, Bellomo R, McArthur C, Myburgh J, Norton R, et al. Impact of albumin compared to saline on organ function and mortality of patients with severe sepsis. Intensive Care Med 2011;37:86-96.

[11] Ulldemolins M, Roberts JA, Rello J, Paterson DL, Lipman J. The effects of hypoalbuminaemia on optimising antibiotic dosing in critically ill patients. Clin Pharmacokinet 2011;50:1-12.

[12] Ulldemolins M, Roberts JA, Lipman J, Rello J. Antibiotic dosing in multiple organ dysfunction syndrome. Chest 2011;139:1210-20.

[13] Wilson AP. Clinical pharmacokinetics of teicoplanin. Clin Pharmacokinet 2000;39:167-83.

[14] Roberts JA, Pea F, Lipman J. The clinical relevance of plasma protein binding changes. Clin Pharmacokinet 2013;52:1-8.

[15] Lipman J, Udy AA, Roberts JA. Do we understand the impact of altered physiology, consequent interventions and resultant clinical scenarios in the intensive care unit? The antibiotic story. Anaesth Intensive Care 2011;39:999-1000. 
[16] Udy AA, Roberts JA, Boots RJ, Paterson DL, Lipman J. Augmented renal clearance: implications for antibacterial dosing in the critically ill. Clin Pharmacokinet 2010;49:1-16.

[17] Udy AA, Roberts JA, Lipman J. Implications of augmented renal clearance in critically ill patients. Nat Rev Nephrol 2011;7:539-43.

[18] Roberts JA, Paul SK, Akova M, Bassetti M, De Waele JJ, Dimopoulos G, et al. DALI: Defining Antibiotic Levels in Intensive care unit patients: are current $\beta$-lactam antibiotic doses sufficient for critically ill patients? Clin Infect Dis 2014 [Epub ahead of print].

[19] Harding I, MacGowan AP, White LO, Darley ES, Reed V. Teicoplanin therapy for Staphylococcus aureus septicaemia: relationship between pre-dose serum concentrations and outcome. J Antimicrob Chemother 2000;45:835-41.

[20] Bilgrami I, Roberts JA, Wallis SC, Thomas J, Davis J, Fowler S, et al. Meropenem dosing in critically ill patients with sepsis receiving high-volume continuous venovenous hemofiltration. Antimicrob Agents Chemother 2010;54:2974-8.
[21] Frye RF, Job ML, Dretler RH, Rosenbaum BJ. Teicoplanin nephrotoxicity: first case report. Pharmacotherapy 1992;12:240-2.

[22] Kureishi A, Jewesson PJ, Rubinger M, Cole CD, Reece DE, Phillips GL, et al. Double-blind comparison of teicoplanin versus vancomycin in febrile neutropenic patients receiving concomitant tobramycin and piperacillin: effect on cyclosporin A-associated nephrotoxicity. Antimicrob Agents Chemother 1991;35:2246-52.

[23] Pea F, Brollo L, Viale P, Pavan F, Furlanut M. Teicoplanin therapeutic drug monitoring in critically ill patients: a retrospective study emphasizing the importance of a loading dose. J Antimicrob Chemother 2003;51: 971-5.

[24] Ulldemolins M, Roberts JA, Wallis SC, Rello J, Lipman J. Flucloxacillin dosing in critically ill patients with hypoalbuminaemia: special emphasis on unbound pharmacokinetics. J Antimicrob Chemother 2010;65:1771-8. 